\title{
Rancang Bangun Prototipe Pengaman Kendaraan Berbasis GPS Komunikasi Pesan Telegram dan Thingspeak
}

\author{
Mukhammad Fatoni $^{1 *}$, Adiananda ${ }^{2}$ \\ ${ }^{1}$ Universitas Bhayangkara Surabaya ${ }^{1}$ \\ *mukhammadfatoni3@gmail.com
}

\begin{abstract}
Vehicle theft cases occur due to various factors, namely: a minimal vehicle security system, lack of supervision and an easy location to commit theft. Motor vehicle theft often occurs when vehicle owners have difficulty tracking vehicles brought by thieves. The purpose of making a vehicle safety system is as a vehicle safety when parking and monitoring vehicle coordinates in real time which is integrated with the thingspeak web server and telegram messages as system control. The design of the tool begins with looking for references from the literature review, designing the system, which includes hardware design and software design, then the system will be tested. The testing and analysis includes testing the response of the device to telegram messages, testing the GPS signal lock, testing the accuracy of GPS data reading, testing the $S W-420$ vibration sensor on the system and testing the system as a whole. The results of testing the tool's response to telegram messages with an average time of 19.8 seconds. The results of the GPS signal lock test with an average time of 266.67 seconds. The results of testing the accuracy of GPS data readings with an average distance difference of 19.99 meters. Vibration sensor test results SW-420 In the system, if the condition of the sensor detects vibration, the sensor output is High so that the buzzer is active and the notification of telegram messages enters the user's telegram account. Overall system testing includes system control mode testing and system information mode testing.
\end{abstract}

Keywords : alarm, GPS, telegram, thingspeak,tracking.

\section{ABSTRAK}

Kasus pencurian kendaraan terjadi karena berbagai faktor, yaitu: sistem keamanan kendaraan yang minim, kurangnya pengawasan dan lokasi mudah untuk melakukan pencurian. Pencurian kendaraan bermotor, sering terjadi pemilik kendaraan kesulitan dalam tracking kendaraan yang dibawa oleh pencuri. Pembuatan sistem pengaman kendaraan bertujuan sebagai pengaman kendaraan pada saat parkir dan monitoring koordinat kendaraan secara real time yang terintegrasi web server thingspeak dan pesan telegram sebagai kontrol sistem. Rancang bangun alat diawali mencari referensi tinjauan pustaka, mendesain sistem, yang meliputi perancangan hardware dan perancangan software, selanjutnya sistem akan diuji. Pengujian dan analisa meliputi pengujian respon alat terhadap pesan telegram, pengujian lock sinyal GPS, pengujian akurasi pembacaan data GPS, pengujian sensor getar SW-420 pada sistem dan pengujian sistem secara keseluruhan. Hasil pengujian respon alat terhadap pesan telegram dengan rata-rata waktu 19.8 second. Hasil pengujian lock sinyal GPS dengan rata-rata waktu 266.67 second. Hasil pengujian akurasi pembacaan data GPS dengan rata-rata selisih jarak 19.99 meter. Hasil pengujian sensor getar SW-420 Pada sistem, jika kondisi sensor mendeteksi getaran maka output sensor High sehingga buzzer aktif dan notifikasi pesan telegram masuk ke akun telegram pengguna. Pengujian sistem secara keseluruhan meliputi pengujian mode kontrol sistem dan pengujian mode informasi sistem.

Kata kunci: alarm, GPS, telegram, thingspeak,tracking.

\section{PENDAHULUAN}

Perkembangan kriminalitas di Indonesia terbilang cukup tinggi, terutama pada pencurian kendaraan. Pada tahun 2019 di Jawa timur menurut jatim.idntimes dari data badan pusat statistik membutktikan kasus curanmor sebanyak 2097 kasus, Jumlah kasus tersebut merupakan cukup tinggi. Kasus pencurian tersebut bisa terjadi karena berbagai faktor, yaitu: sistem keamanan kendaraan yang minim, kurangnya 
pengawasan dan lokasi yang mudah untuk melakukan pencurian [1].

Saat ini pihak yang memproduksi kendaraan bermotor telah memasang alarm sebagai indikator sistem pengaman standar. Alarm ini menghasilkan suara melalui buzzer yang terpasang pada kendaraan, mempunyai fungsi pemberi peringatan pada pemilik kendaraan, akan tetapi alarm ini baru tersedia pada kendaraan keluaran terbaru [2].

Pada kasus pencurian kendaraan bermotor yang sering terjadi pemilik kendaraan selalu kesulitan dalam menelusuri jejak kendaraan yang dibawa oleh pencuri. Oleh karena itu sistem pelacak dan alarm sangat diperlukan pada kendaraan bermotor saat ini sebagai alat keamanan. Oleh karena itu diperlukan sebuah sistem yang mudah digunakan oleh semua orang untuk mengatasi masalah tersebut [3].

IOT (Internet of Things) adalah sebuah konsep komputasi bahwa setiap obyek fisik saling terhubung dengan internet dan dapat mengidentifikasi dengan otomatis antar perangkat. Dimana user dapat mengontrol, mengelola dan mengoptimalkan peralatan elektronik dengan jarak jauh menggunakan media internet. GPS (Global Position System) adalah sistem navigasi sistem komunikasinya menggunakan satelit yang didesain untuk mendapatkan letak titik koordinat posisi sebuah objek secara cepat dan akurat dibelahan bumi ini [4]-[6].

Telegram merupakan aplikasi pesan yang berfokus pada performa dan tingkat keamanan yang lebih dengan tampilan sederhana serta gratis dalam pengunaanya. Aplikasi telegram dapat digunakan di perangkat ponsel smartphone, tablet, serta komputer [7].

Web server thingspeak.com merupakan web open source Internet of Things yang berfungsi menyimpan dan mengambil data dari hal-hal yang menggunakan protokol HTTP melalui internet atau melalui Local Area Network. Thingspeak memungkinkan pembuatan aplikasi logging sensor, aplikasi pelacak lokasi, dan jaringan sosial dari hal-hal dengan update status [8].

\section{METODE PENELITIAN}

\subsection{Gambaran Umum}

Pembuatan sistem pengaman kendaraan bertujuan sebagai sistem pengaman (alarm) kendaraan pada saat parkir dan monitoring koordinat kendaraan secara real time dengan terintegrasi web server thingspeak.com dan pesan telegram sebagai kontrol sistem pengaman kendaraan. Berikut gambaran dari sistem pengaman kendaraan:

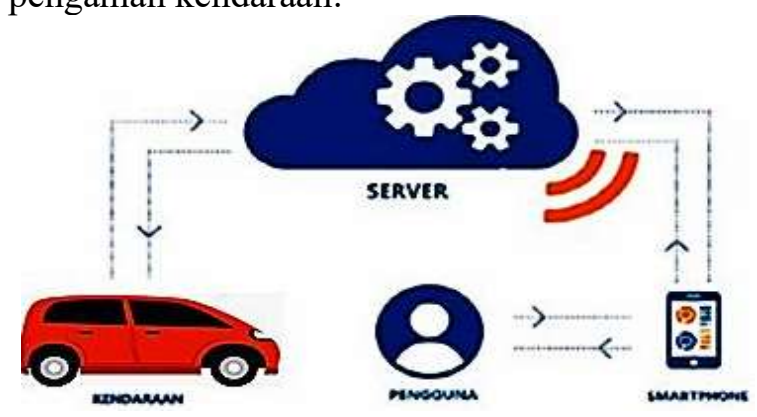

Gambar 1. Sistem Komunikasi Pada Pengaman Kendaraan ${ }^{[2]}$.

\subsection{Rancangan Bangun Penelitian}

Rancangan bangun penelitian diawali dengan mencari referensi tinjauan pustaka, kemudian mendesain sistem yang meliputi perancangan hardware dan perancangan software selanjutnya sistem akan diuji apakah sesuai dengan parameter yang ditentukan. Rancangan bangun penelitian ditunjukkan dalam bentuk diagram alir pada gambar 2 .

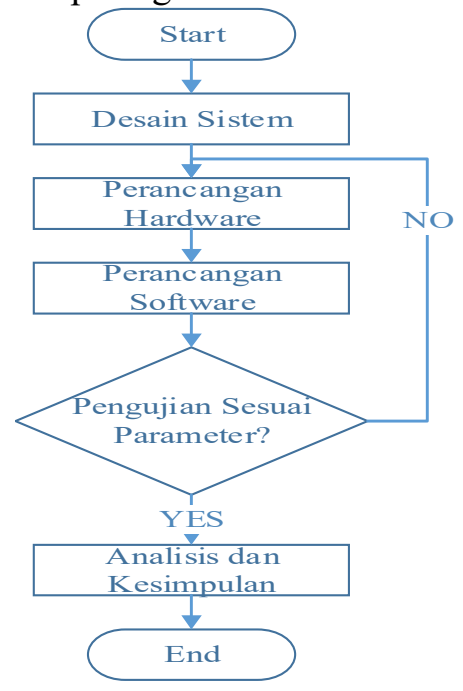

Gambar 2. Rancangan Bangun Penelitian ${ }^{[4]}$. 
Jurnal ELECTRON, Vol. 2, No.2, November 2021, Hal. 57-68

e-ISSN 2622-6588 / p-ISSN 2830-523X

DOI: 10.33019\electron.v2i2.1

\subsection{Perancangan Hardware}

Perancangan hardware sistem pengaman kendaraan berbasis GPS komunikasi pesan telegram dan thingspeak, diawali dengan membuat blok diagram sistem, perancangan skematik rangkaian dan perancangan mekanik. Untuk Blok Diagram perancangan pada gambar 3.

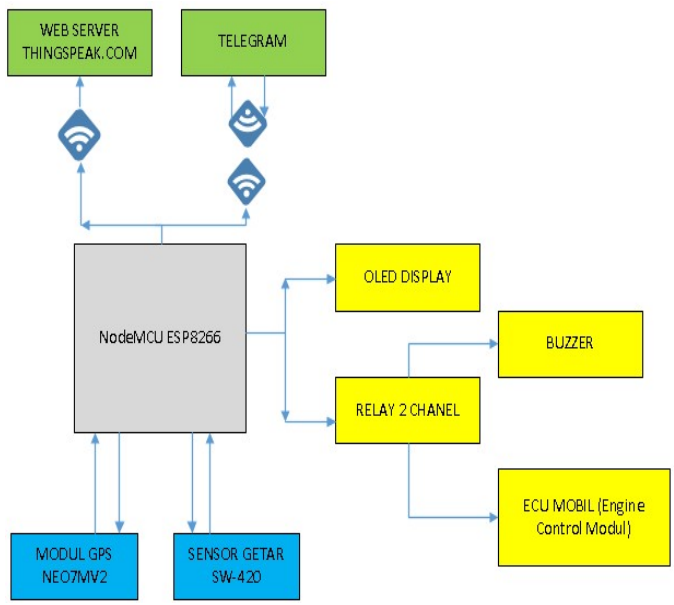

Gambar 3. Blok Diagram Sistem.

\subsubsection{Perancangan Elektrik}

Skematik rangkaian sistem pengaman kendaraan pada penelitian ini ditunjukkan pada gambar 4.

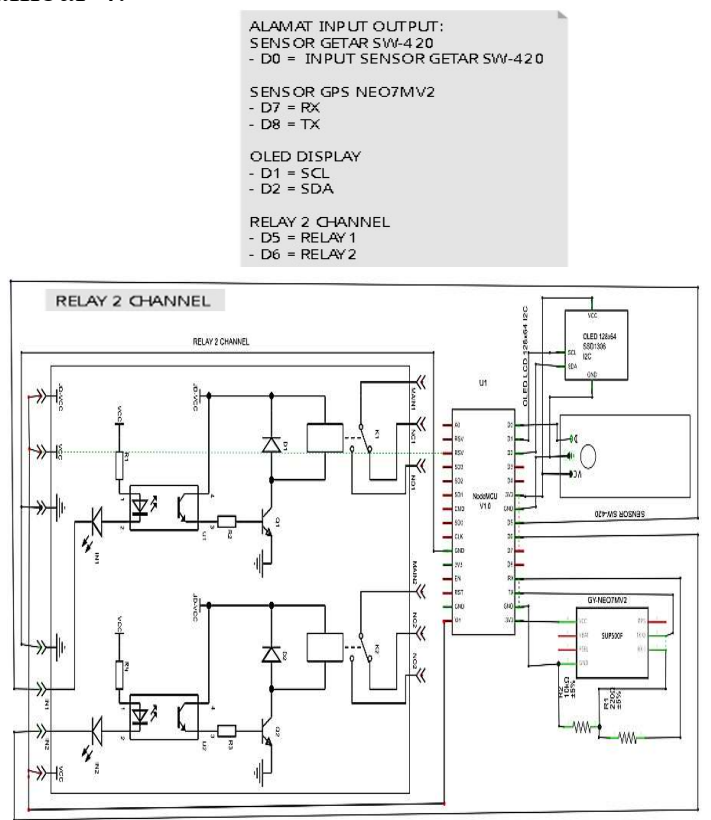

Gambar 4. Skematik Rangkaian.

\subsubsection{Perancangan Mekanik}

Perancangan mekanik dibuat dengan gambar berbentuk box yang rencana digunakan sebagai casing rangkaian sistem pengaman kendaraan yang ditampilkan pada gambar 5 dan gambar 6

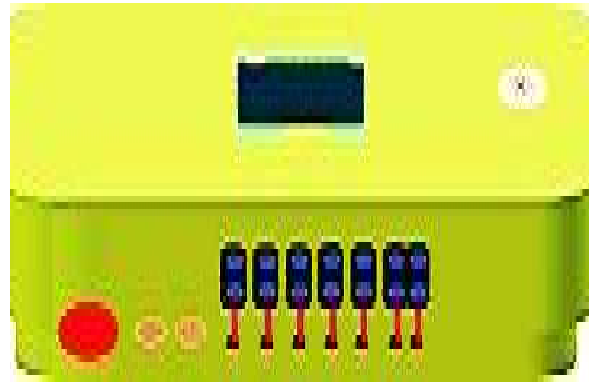

Gambar 5. Desain Box Bagian Luar.

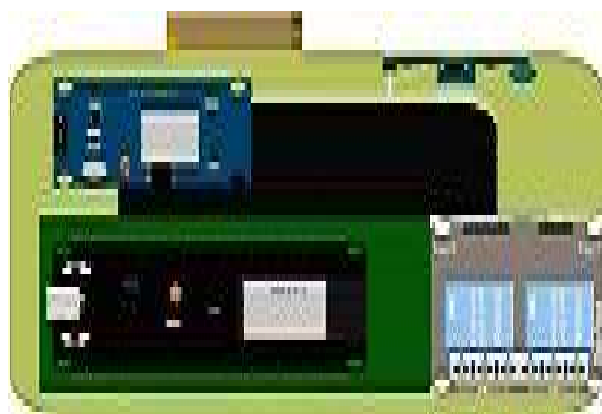

Gambar 6. Desain Box Bagian Dalam.

\subsection{Perancangan Software}

Perancangan software pengaman kendaraan berbasis GPS komunikasi pesan telegram dan thingspeak meliputi flow chart, flow chart dari pengaman kendaraan berbasis GPS komunikasi pesan telegram dan thingspeak diuraikan sebagai berikut:

\section{Program Utama Pengaman Kendaraan}

Pada gambar 7 flowchart prototipe pengaman kendaraan berbasis GPS dengan komunikasi pesan telegram dan thingspeak diawali menginisialisasi semua komponen yang digunakan diantaranya NodeMCU ESP8266, modul GPS NE07MV2, sensor getar SW-420, oled display, relay 2 channel. Terdapat data koordinat dan data getar, data koordinat dikirim ke server thingspeak. Jika server thingspeak terhubung maka data koordinat akan diperbarui pada server thingspeak. 


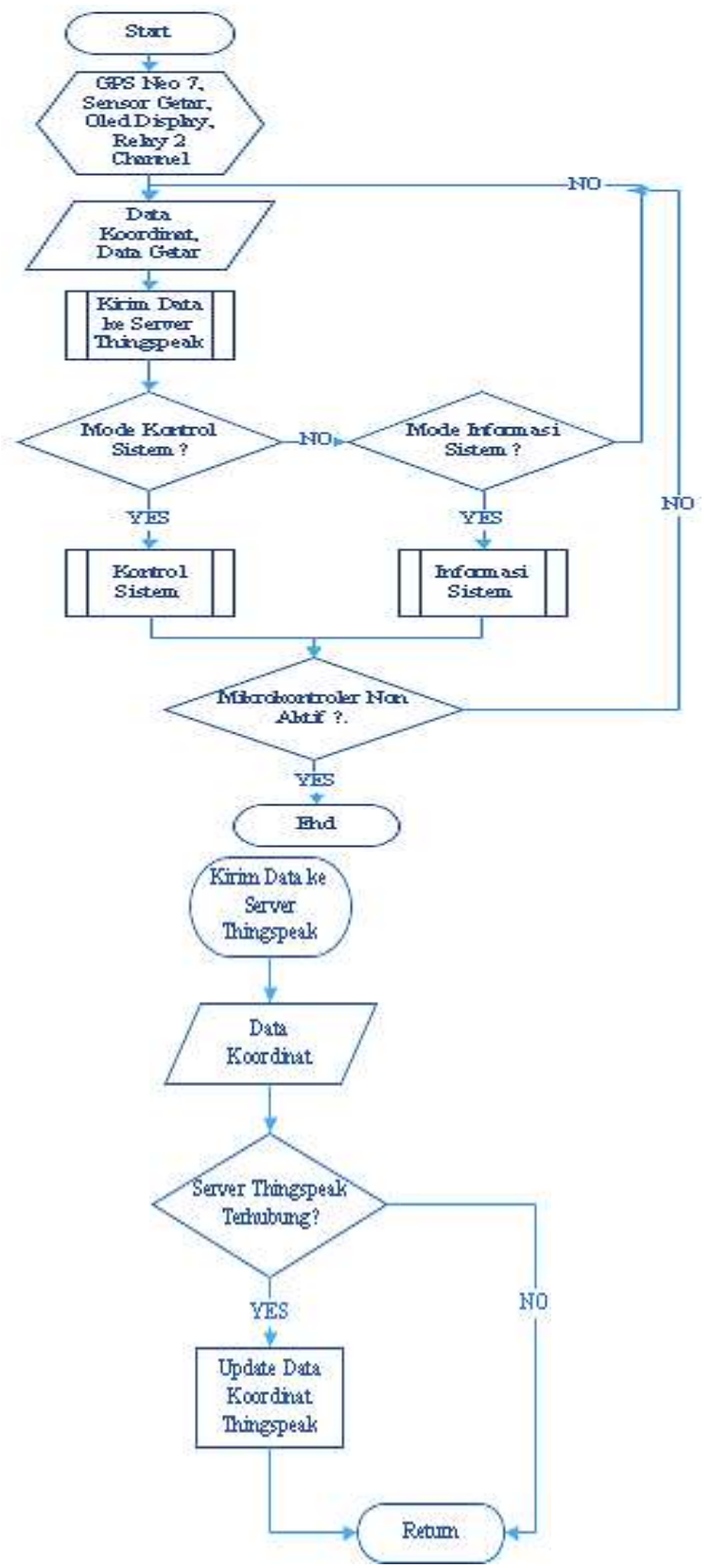

Gambar 7. Flow Chart Program Utama Pengaman Kendaraan.

Pengaman kendaraan berbasis GPS komunikasi pesan telegram dan thingspeak ini terdapat 2 mode terdiri dari mode kontrol sistem dan mode informasi sistem.

\section{Mode Kontrol Sistem}

Pada gambar 8 berfungsi sebagai kontrol sistem pengaman kendaraan berbasis GPS komunikasi pesan telegram dan thingspeak yang terdiri dari kondisi kendaraan saat parkir, driver dan mode disable.

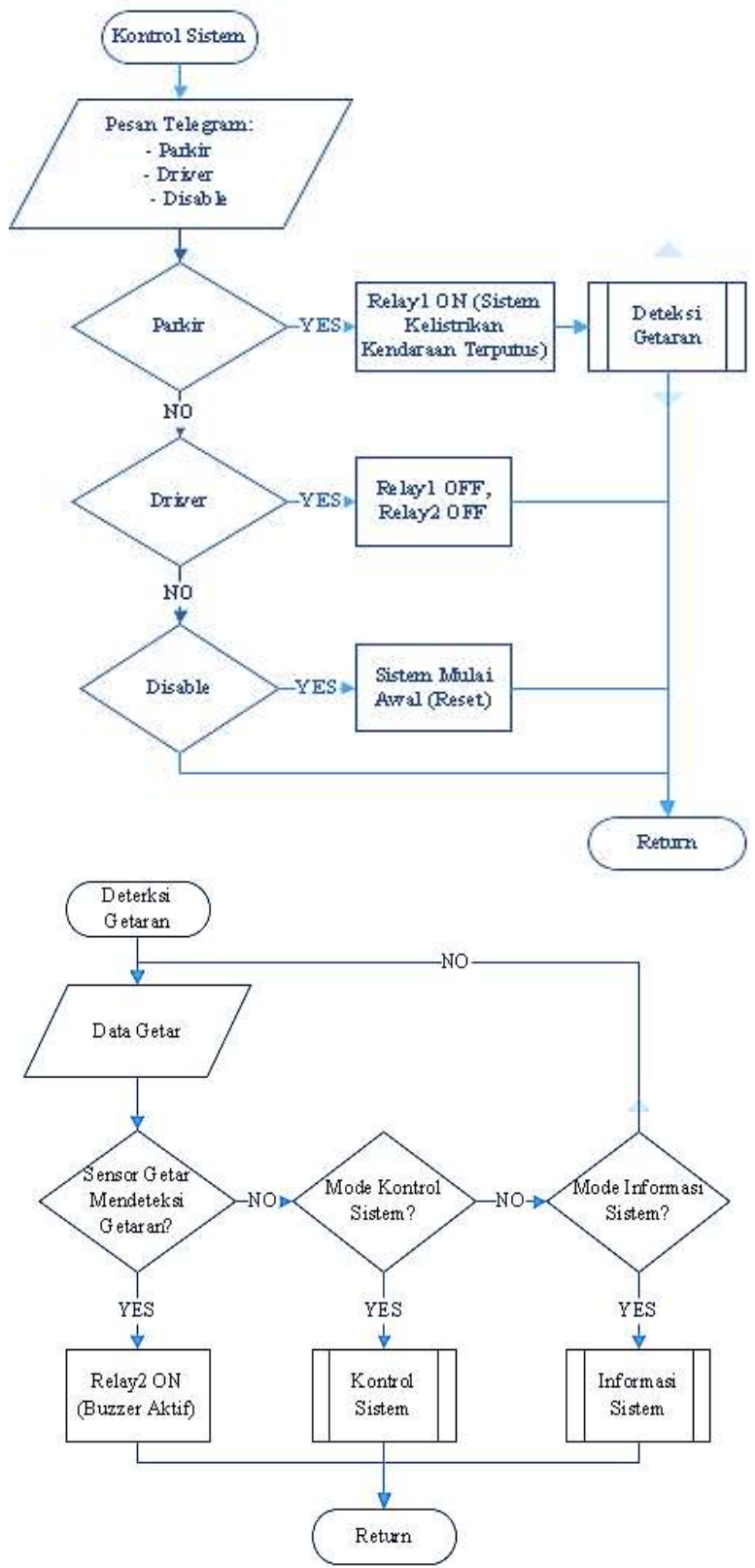

Gambar 8. Flow Chart Mode Kontrol.

\section{Mode Informasi Sistem}

Pada gambar 9 mode informasi sistem keamanan bertujuan untuk menginformasikan status sistem yang sedang aktif tanpa mengganggu jalanya kontrol sistem. Mode informasi sistem keamanan terdiri dari status buzzer, status sistem kendaraan dan status lokasi kendaraan. 
Jurnal ELECTRON, Vol. 2, No.2, November 2021, Hal. 57-68

e-ISSN 2622-6588 / p-ISSN 2830-523X

DOI: 10.33019\electron.v2i2.1

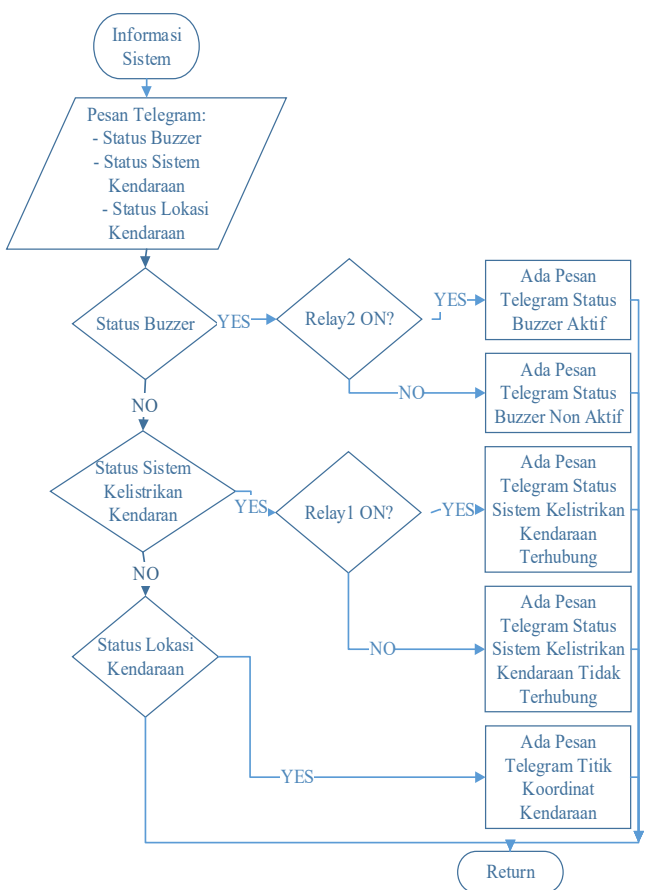

Gambar 9. Flow Chart Mode Informasi Sistem Keamanan.

\section{HASIL PENELITIAN DAN PEMBAHASAN}

\subsection{Metode Pengujian}

Ada beberapa tahapan pengujian yang dilakukan untuk mencapai sistem yang baik pada pengaman kendaraan. Pengujian tersebut antara lain: pengujian respon alat terhadap pesan telegram yang dikirim, pengujian lock sinyal GPS untuk, pengujian sensor getar, pengujian pembacaan data GPS dan pengujian sistem secara keseluruhan.

\subsection{Hasil Perancangan Alat}

Hasil perancangan alat di tampilkan pada gambar 10 berupa rangkaian pengaman kendaraan dan gambar 11 berupa box alat sistem pengaman kendaraan.

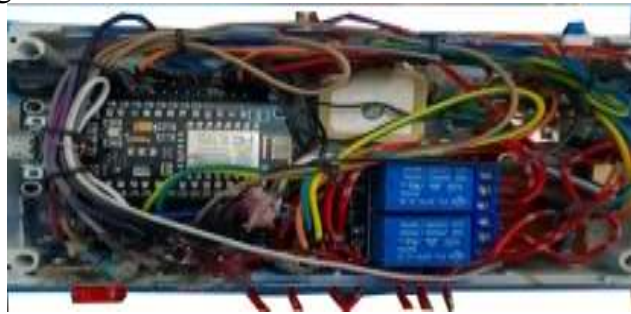

Gambar 10. Kelistrikan Alat Pengaman Kendaraan.

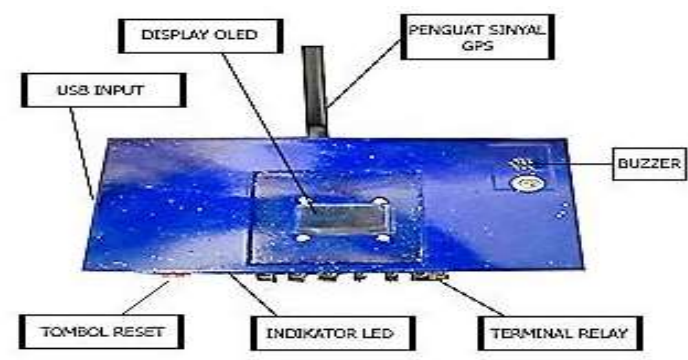

Gambar 11. Box Alat Pengaman Kendaraan.

\subsection{Peralatan Yang Digunakan}

Berikut peralatan yang digunakan untuk melakukan pengujian terhadap prototipe pengaman kendaraan, antara lain: prototipe pengaman kendaraan yang sudah dibuat, laptop atau komputer, handphone, kabel USB mikro dan mifi atau wifi.

\subsection{Pengujian Respon Alat Terhadap Pesan Telegram}

Pengujian ini bertujuan untuk menggetahui lama waktu respon balasan pesan dari alat pengaman kendaraan terhadap pesan telegram yang dikirimkan ke bot telegram.

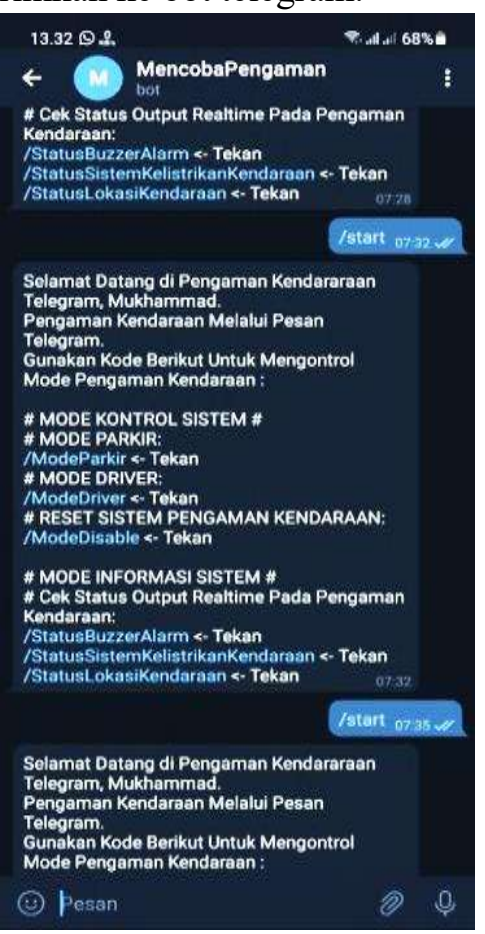

Gambar 12. Pesan Ke Bot Telegram. 
Jurnal ELECTRON, Vol. 2, No.2, November 2021, Hal. 57-68

e-ISSN 2622-6588 / p-ISSN 2830-523X

DOI: 10.33019\electron.v2i2.1

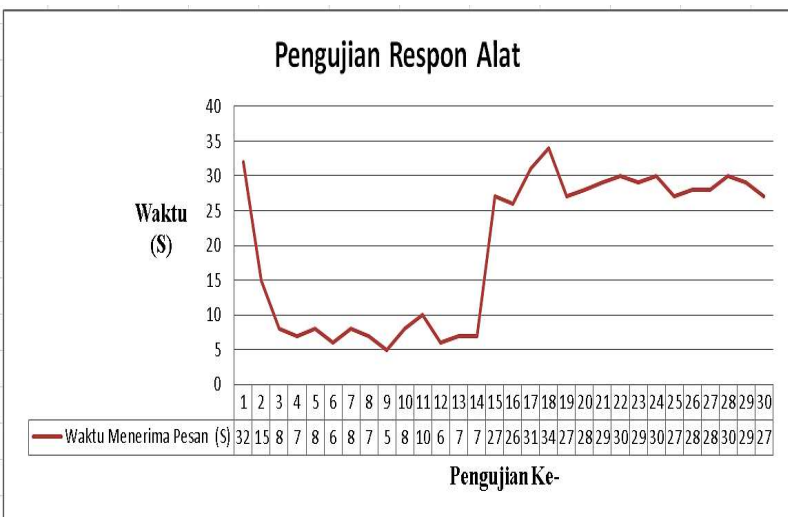

Gambar 13. Grafik Hasil Pengujian Respon Alat.

Tabel 1. Hasil Pengujian Waktu Respon Balasan Pesan Alat Pengaman Kendaraan.

\begin{tabular}{|c|c|c|}
\hline No. & $\begin{array}{c}\text { Pengujian } \\
\text { Ke- }\end{array}$ & \begin{tabular}{|c|} 
Waktu Menerima Pesan \\
(S)
\end{tabular} \\
\hline 1 & 1 & 32 \\
\hline 2 & 2 & 15 \\
\hline 3 & 3 & 8 \\
\hline 4 & 4 & 7 \\
\hline 5 & 5 & 8 \\
\hline 6 & 6 & 6 \\
\hline 7 & 7 & 8 \\
\hline 8 & 8 & 7 \\
\hline 9 & 9 & 5 \\
\hline \begin{tabular}{|l|}
10 \\
\end{tabular} & 10 & 8 \\
\hline \begin{tabular}{|l|}
11 \\
\end{tabular} & 11 & 10 \\
\hline \begin{tabular}{|l|}
12 \\
\end{tabular} & 12 & 6 \\
\hline \begin{tabular}{|l|}
13 \\
\end{tabular} & 13 & 7 \\
\hline \begin{tabular}{|l|}
14 \\
\end{tabular} & 14 & 7 \\
\hline 15 & 15 & 27 \\
\hline \begin{tabular}{|l|}
16 \\
\end{tabular} & 16 & 26 \\
\hline \begin{tabular}{|l|}
17 \\
\end{tabular} & 17 & 31 \\
\hline \begin{tabular}{|l|}
18 \\
\end{tabular} & 18 & 34 \\
\hline \begin{tabular}{|l|}
19 \\
\end{tabular} & 19 & 27 \\
\hline \begin{tabular}{|l|}
20 \\
\end{tabular} & 20 & 28 \\
\hline \begin{tabular}{|l|}
21 \\
\end{tabular} & 21 & 29 \\
\hline \begin{tabular}{|l|}
22 \\
\end{tabular} & 22 & 30 \\
\hline \begin{tabular}{|l|}
23 \\
\end{tabular} & 23 & 29 \\
\hline \begin{tabular}{|l|}
24 \\
\end{tabular} & 24 & 30 \\
\hline \begin{tabular}{|l|}
25 \\
\end{tabular} & 25 & 27 \\
\hline \begin{tabular}{|l|}
26 \\
\end{tabular} & 26 & 28 \\
\hline \begin{tabular}{|l|}
27 \\
\end{tabular} & 27 & 28 \\
\hline \begin{tabular}{|l|}
28 \\
\end{tabular} & 28 & 30 \\
\hline \begin{tabular}{|l|}
29 \\
\end{tabular} & 29 & 29 \\
\hline \begin{tabular}{|l|}
30 \\
\end{tabular} & 30 & 27 \\
\hline \multicolumn{2}{|c|}{ Waktu Minimum (S) } & 5 \\
\hline \multicolumn{2}{|c|}{ Waktu Maksimum (S) } & 34 \\
\hline \multicolumn{2}{|c|}{ Rata-rata Waktu (S) } & 19,8 \\
\hline
\end{tabular}

Dilihat dari data pada tabel 1. dapat disimpulkan bahwa lama waktu respon balasan pesan dari alat pengaman kendaraan terhadap pesan telegram yang dikirimkan ke bot telegram dengan waktu minimum yaitu 5 second, waktu maksimum yaitu 34 second dan rata-rata waktu respon balasan pesan yaitu 19.8 second.

\subsection{Pengujian Lock Sinyal GPS}

Pengujian ini bertujuan untuk menggetahui lama waktu sensor GPS NEO7MV2 pada pengaman kendaraan mendeteksi sinyal satelit GPS. Data koordinat diperoleh melalui serial monitor atau di web server thingspeak.

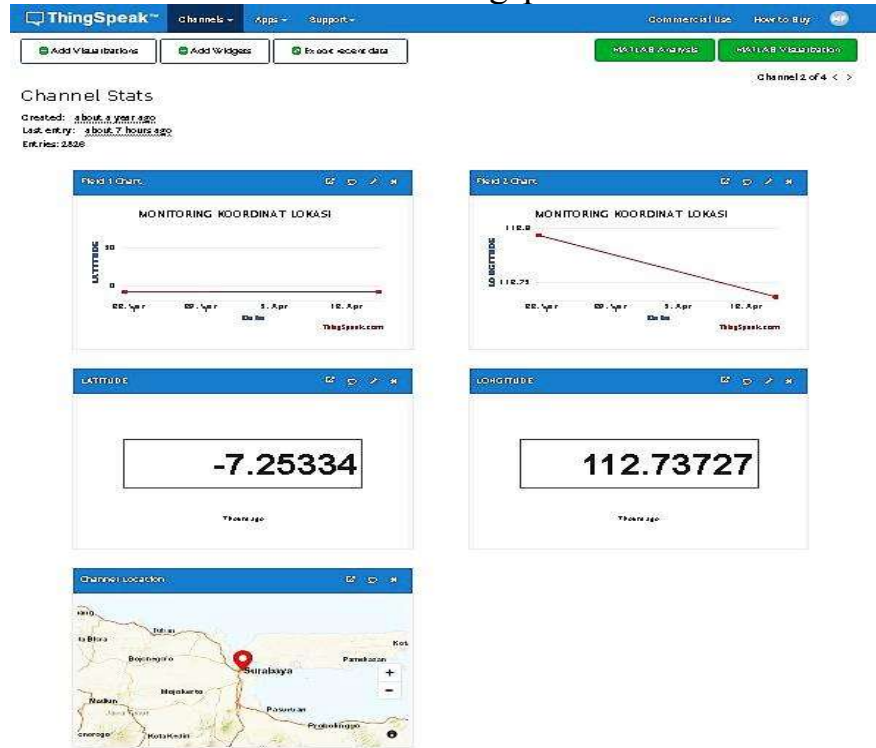

Gambar 14. Thingspeak Ketika Sensor GPS Lock Sinyal.

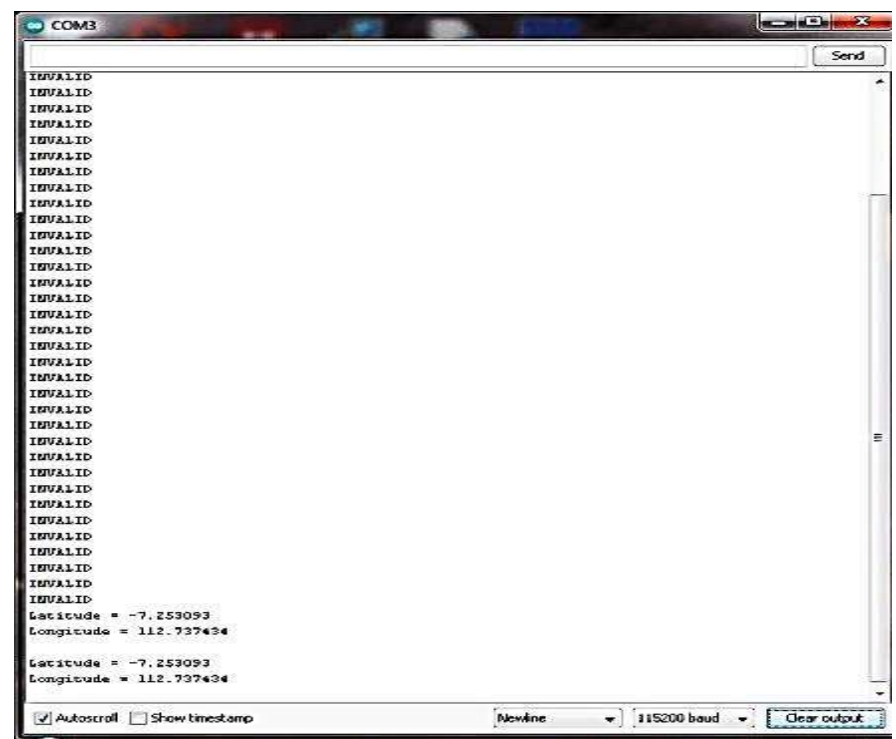

Gambar 15. Serial Monitor Ketika Sensor GPS Lock Sinyal. 
Jurnal ELECTRON, Vol. 2, No.2, November 2021, Hal. 57-68

e-ISSN 2622-6588 / p-ISSN 2830-523X

DOI: 10.33019\electron.v2i2.1

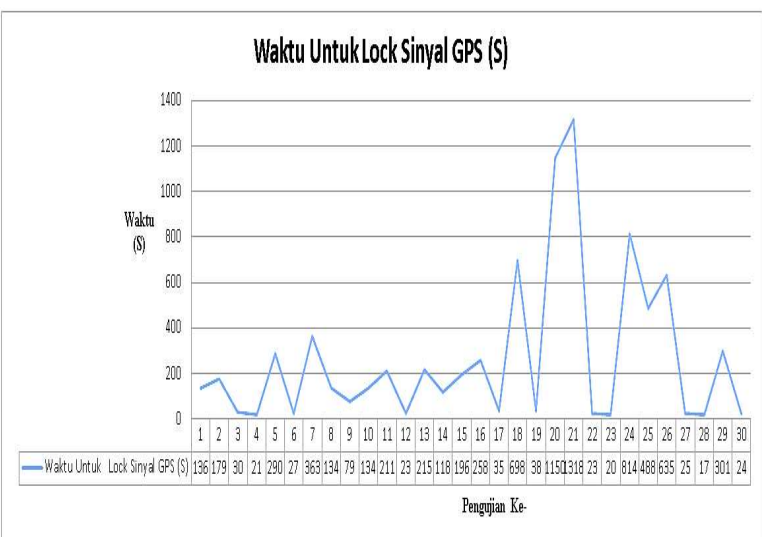

Gambar 16. Grafik Hasil Pengujian Lock Sinyal GPS.

Tabel 2. Hasil Pengujian Lock Sinyal GPS.

\begin{tabular}{|c|c|c|c|c|}
\hline \multirow{2}{*}{ No. } & \multirow{2}{*}{ 'engujian Ke } & \multicolumn{2}{|c|}{$\begin{array}{c}\text { Koordinat GPS } \\
\text { Sistem Pengaman Kendaraan } \\
\end{array}$} & \multirow{2}{*}{$\begin{array}{c}\text { Waktu Untuks } \\
\text { Lock Sinyal GPS } \\
\text { (S) } \\
\end{array}$} \\
\hline & & & & \\
\hline 1 & 1 & $-7,253332$ & 112,737152 & \\
\hline 2 & 2 & $-7,253093$ & 112,737434 & 179 \\
\hline 3 & 3 & $-7,253150$ & 112,737335 & 30 \\
\hline 4 & 4 & $-7,253318$ & 112,737061 & 21 \\
\hline 5 & 5 & $-7,253304$ & 112,737114 & 290 \\
\hline 6 & 6 & $-7,253275$ & 112,736992 & 27 \\
\hline 7 & 7 & $-7,253367$ & 112,737465 & 363 \\
\hline 8 & 8 & $-7,253309$ & 112,737228 & 134 \\
\hline 9 & 9 & $-7,253313$ & 112,737198 & 79 \\
\hline 10 & 10 & $-7,253292$ & 112,737099 & 134 \\
\hline 11 & 11 & $-7,253299$ & 112,736862 & 211 \\
\hline 12 & 12 & $-7,253307$ & 112,737045 & 23 \\
\hline 13 & 13 & $-7,253333$ & 112,737206 & 215 \\
\hline 14 & 14 & $-7,253349$ & 112,737312 & 118 \\
\hline 15 & 15 & $-7,253325$ & 112,736877 & 196 \\
\hline 16 & 16 & $-7,253360$ & 112,736595 & 258 \\
\hline 17 & 17 & $-7,253360$ & 112,736870 & 35 \\
\hline 18 & 18 & $-7,2533336$ & 112,737221 & 698 \\
\hline 19 & 19 & $-7,253319$ & 112,737198 & 38 \\
\hline 20 & 20 & $-7,253338$ & 112,737267 & 1150 \\
\hline 21 & 21 & $-7,2533445$ & 112,737175 & 1318 \\
\hline 22 & 22 & $-7,253481$ & 112,737152 & 23 \\
\hline 23 & 23 & $-7,253338$ & 112,737297 & 20 \\
\hline 24 & 24 & $-7,253323$ & 112,737152 & 814 \\
\hline 25 & 25 & $-7,253352$ & 112,737022 & 488 \\
\hline 26 & 26 & $-7,253340$ & 112,737305 & 635 \\
\hline 27 & 27 & $-7,253347$ & 112,737312 & 25 \\
\hline 28 & 28 & $-7,253323$ & 112,737282 & 17 \\
\hline 29 & 29 & $-7,253313$ & 112,737282 & 301 \\
\hline 30 & 30 & $-7,253306$ & 112,737411 & 24 \\
\hline \multicolumn{4}{|c|}{ Waktu Minimum Untuk Lock Sinyal GPS (S) } & 17 \\
\hline \multirow{2}{*}{\multicolumn{4}{|c|}{$\begin{array}{l}\text { Waktu Maksimum Untuk Lock Sinyal GPS (S) } \\
\text { Rata-rata Wahtu Untuk Lock Sinyal GPS (S) }\end{array}$}} & 1318 \\
\hline & & & & 266,67 \\
\hline
\end{tabular}

Dari tabel 2 dapat disimpulkan bahwa waktu minimum untuk lock sinyal GPS pada pengaman kendaraan yaitu 17 second, waktu maksimum yaitu 1318 second atau setara dengan 21 menit 58 detik dan rata-rata waktu untuk GPS lock sinyal yaitu 266.67 second atau setara dengan 44 menit 45 detik.

\subsection{Pengujian Akurasi Pembacaan Data GPS}

Pengujian ini dilakukan untuk menggetahui keakuratan sistem pengaman kendaraan dalam melakukan tracking lokasi. Hasil tracking lokasi yang didapatkan pada sensor GPS NEO7MV2 akan dibandingkan dengan titik koordinat pada aplikasi google maps dari GPS handphone.
Perbandingan hasil tracking selisih jarak menggunakan Teori Pengukuran Jarak Euclidean distance. Euclidean distance $(\mathrm{d})=$ $\sqrt{\left(X_{1}-X_{2}\right)^{2}+\left(Y_{1}-Y_{2}\right)^{2}}$

Sehingga dari perhitungan diatas kita dapat implementasi menjadi Rumus Jarak Euclide: $\sqrt{\left(L^{2} t_{1}-L_{L} t_{2}\right)^{2}+\left(L_{o n g}-L_{1} \operatorname{long}_{2}\right)^{2}}$

Hasil perhitungan diatas masih dalam satuan decimal degree, sehingga untuk menyesuaikannya butuh dikalikan dengan $111.319 \mathrm{~km}$ (1 derajat bumi $=111.319 \mathrm{~km})[23]$.

Hasil pengujian pada bagian 3.5 akan dibandingkan dengan titik koordinat yang didapat pada aplikasi google maps dari GPS handphone samsung A51.

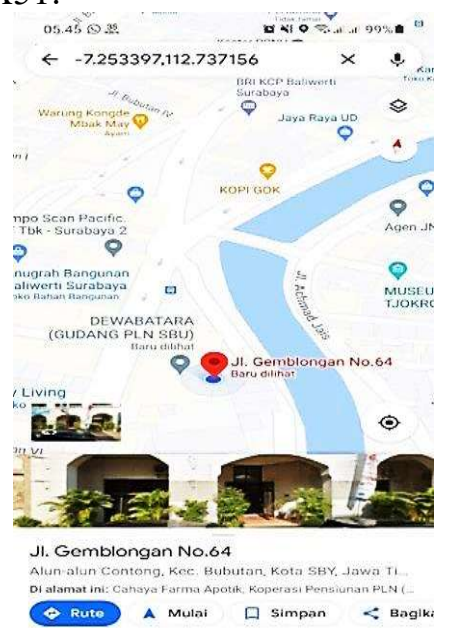

Gambar 17. Titik Koordinat Pada Aplikasi Google Maps Dari GPS Handphone.

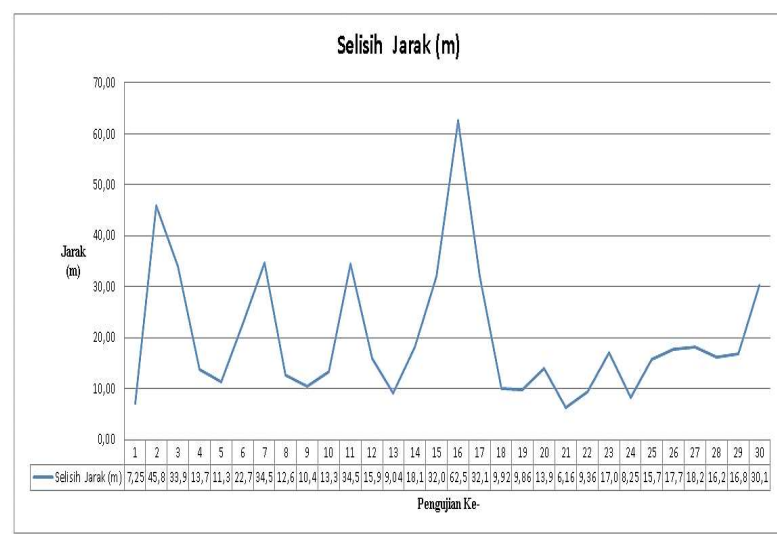

Gambar 18. Grafik Hasil Pengujian Akurasi Data GPS. 
Jurnal ELECTRON, Vol. 2, No.2, November 2021, Hal. 57-68

e-ISSN 2622-6588 / p-ISSN 2830-523X

DOI: 10.33019\electron.v2i2.1

Tabel 3. Hasil Pengujian Akurasi Pembacaan Data GPS.

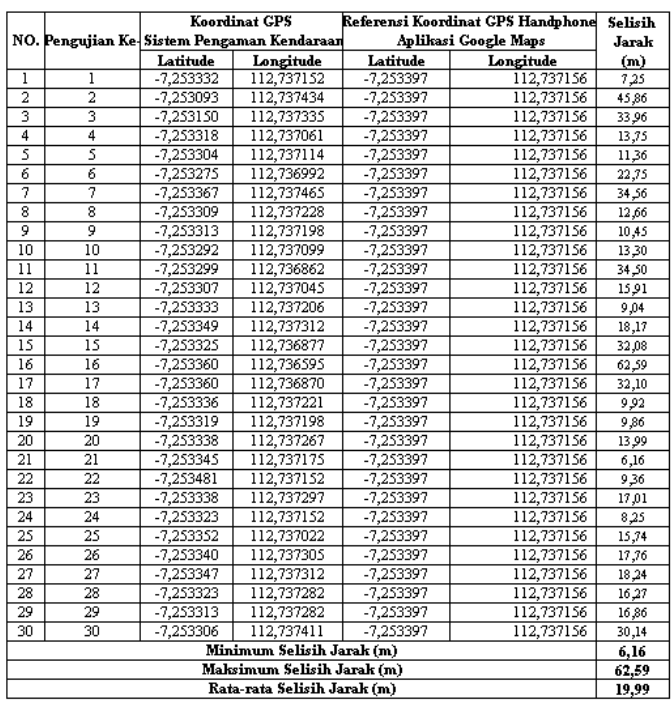

Dari tabel 3 dapat disimpulkan bahwa minimum selisih jarak untuk akurasi pembacaan data GPS pada pengaman kendaraan yaitu 6.16 meter, untuk maksimum selisih jarak yaitu 62.59 meter dan rata-rata selisih jarak untuk akurasi pembacaan data GPS yaitu 19.99 meter.

\subsection{Pengujian Sensor Getar SW-420 Pada Sistem}

Pengujian ini bertujuan untuk memeriksa kondisi sensor getar pada pengaman kendaraan. Sehingga ketika terjadi getaran pada kendaraan, pengaman kendaraan dapat mengirimkan notifikasi pesan telegram ke akun telegram pengguna dan mengaktifkan buzzer pada pengaman kendaraan.

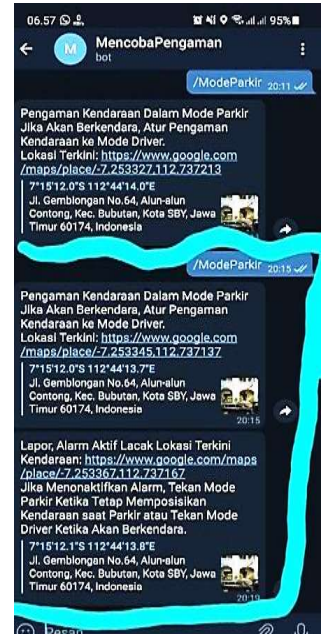

Gambar 19. Ketika Sensor Getar SW-420 Aktif dan Mengirim Notifikasi Pesan Telegram.
Tabel 4. Hasil Pengujian Sensor Getar SW-420.

\begin{tabular}{|c|c|c|c|c|}
\hline No. & $\begin{array}{c}\text { Pengujian } \\
\text { Ke- }\end{array}$ & $\begin{array}{c}\text { Sumber Tegangan } \\
\text { (VIn) } \\
\text { Sensor Getar SW-420 }\end{array}$ & Getaran & $\begin{array}{c}\text { Buzzer Pada Pengaman Kendaraan } \\
\text { Berbunyi dan Ada Pesan Telegram Masuk } \\
\text { (YATDAK) }\end{array}$ \\
\hline 1 & 1 & $3,3 \mathrm{~V}$ & Low & Tidak \\
\hline 2 & 2 & $3,3 \mathrm{~V}$ & High & YA \\
\hline
\end{tabular}

Dari tabel 4 dapat disimpulkan bahwa jika kondisi sensor SW-420 aktif (mendeteksi getaran) maka output sensor getar akan High sehingga buzzer pada pengaman kendaraan berbunyi dan ada notifikasi pesan telegram masuk ke akun telegram pengguna.

\subsection{Pengujian Sistem Secara Keseluruhan}

Tujuan dari pengujian ini bertujuan untuk menggetahui sistem apakah sudah dapat beroperasi dengan baik sesuai dari tujuan penelitian. Pengujian sistem secara keseluruhan, meliputi sebagai berikut:

\subsubsection{Pengujian Mode Kontrol Sistem}

Pengujian mode kontrol sistem meliputi: pengujian pengaman kendaraan ketika mode parkir, pengujian pengaman kendaraan ketika mode driver dan pengujian pengaman kendaraan mode disable, yang dijabarkan sebagai berikut:

\section{Pengujian Pengaman Kendaraan Ketika Mode Parkir}

Pengujian ini dilakukan ketika kendaraan pada saat posisi parkir. Pengujian ini dilakukan dengan mengirimkan pesan /ModeParkir ke bot telegram yang bertujuan untuk mengaktifkan mode parkir pengaman kendaraan terlihat pada gambar 19.

\section{Pengujian Pengaman Kendaraan Ketika} Mode Driver

Pengujian ini dilakukan ketika akan memakai kendaraan dengan mengirimkan pesan /ModeDriver ke bot telegram dengan tujuan untuk mengaktifkan mode driver pengaman kendaraan yang bertujuan menyambungkan sistem kelistrikan ECU (Engine Control Module) dengan sumber listrik kendaraan (aki). 
Jurnal ELECTRON, Vol. 2, No.2, November 2021, Hal. 57-68

e-ISSN 2622-6588 / p-ISSN 2830-523X

DOI: 10.33019\electron.v2i2.1

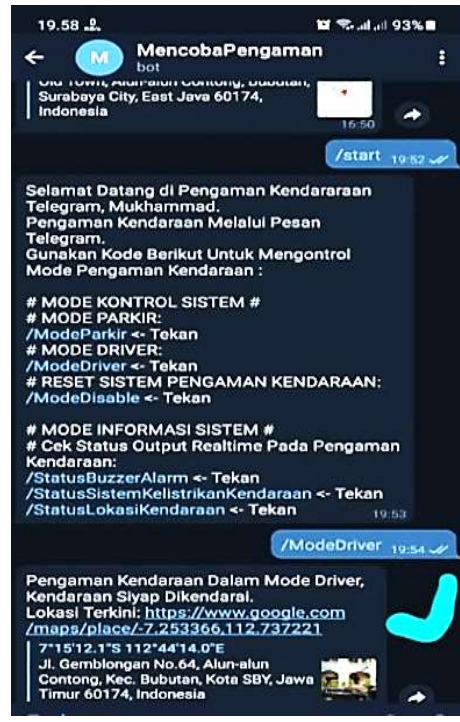

Gambar 20. Pesan /ModeDriver ke bot Telegram.

\section{- Pengujian Pengaman Kendaraan Mode Disable}

Pengujian ini dilakukan ketika sistem pengaman kendaraan terjadi hal yang tidak sesuai ditentukan, dengan mengirimkan pesan /ModeDisable ke bot telegram yang bertujuan untuk mereset sistem pengaman kendaraan sehingga sistem pengaman kendaraan berjalan seperti ketika awal di hidupkan.

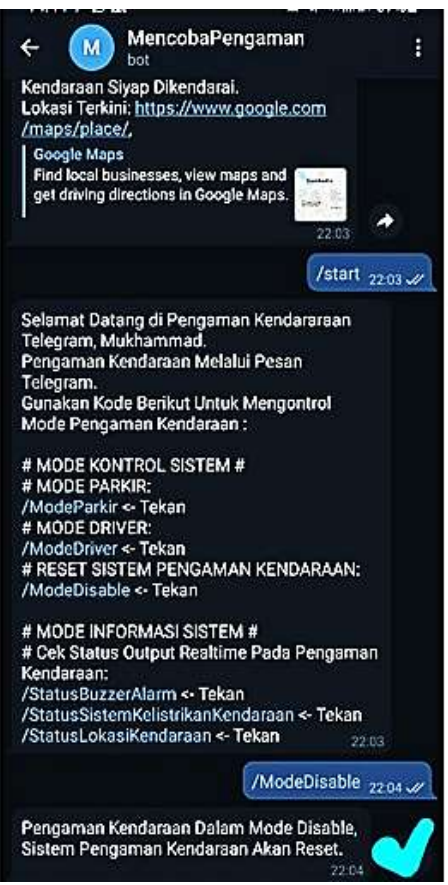

Gambar 21. Pesan /ModeDisable ke bot Telegram.

\subsubsection{Pengujian Mode Informasi Sistem}

Pengujian mode informasi sistem meliputi: pengujian status buzzer alarm kendaraan, pengujian status sistem kelistrikan kendaraan dan pengujian status lokasi kendaraan, yang dijabarkan sebagai berikut:

\section{Pengujian Status Buzzer Alarm Kendaraan}

Pengujian ini dilakukan untuk menggetahui status buzzer pada pengaman kendaraan apakah aktif atau tidak, dengan mengirimkan pesan /StatusBuzzerAlarm ke bot telegram.

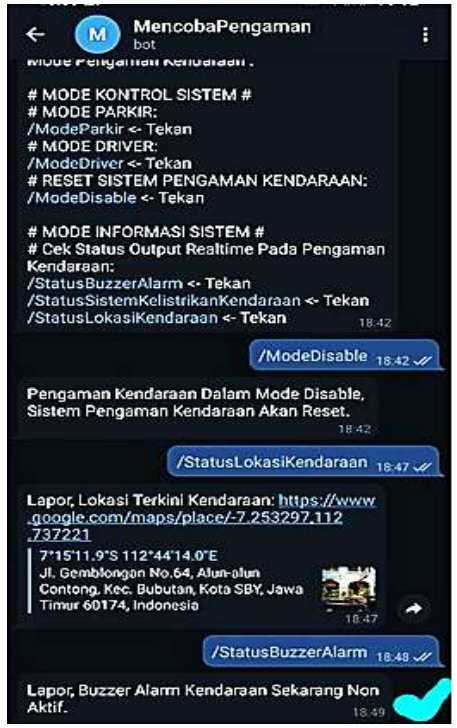

Gambar 22. Pesan/StatusBuzzerAlarm ke bot Telegram.

\section{Pengujian Status Sistem Kelistrikan Kendaraan}

Pengujian ini dilakukan untuk menggetahui status sistem kelistrikan pada ECU Engine Control Module di pengaman kendaraan, apakah tersambung atau tidak dengan sumber kelistrikan kendaraan. Pengujian ini dilakukan dengan mengirimkan pesan /StatusSistemKelistrikanKendaraan ke bot telegram. 
Jurnal ELECTRON, Vol. 2, No.2, November 2021, Hal. 57-68

e-ISSN 2622-6588 / p-ISSN 2830-523X

DOI: 10.33019\electron.v2i2.1

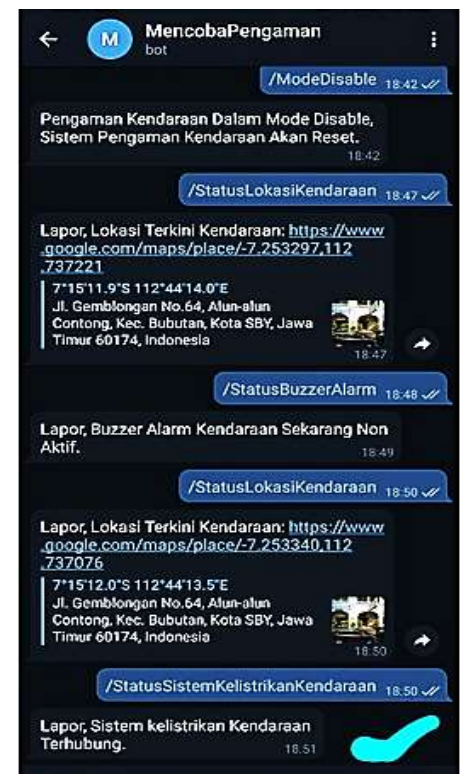

Gambar 23. Pesan

/StatusSistemKelistrikanKendaraan ke bot Telegram.

\section{Pengujian Status Lokasi Kendaraan}

Pengujian ini dilakukan untuk menggetahui status lokasi terkini kendaraaan dengan titik koordinat yang dikirim oleh bot telegram. Pengujian ini dilakukan dengan mengirimkan pesan /StatusLokasiKendaraan ke bot telegram.

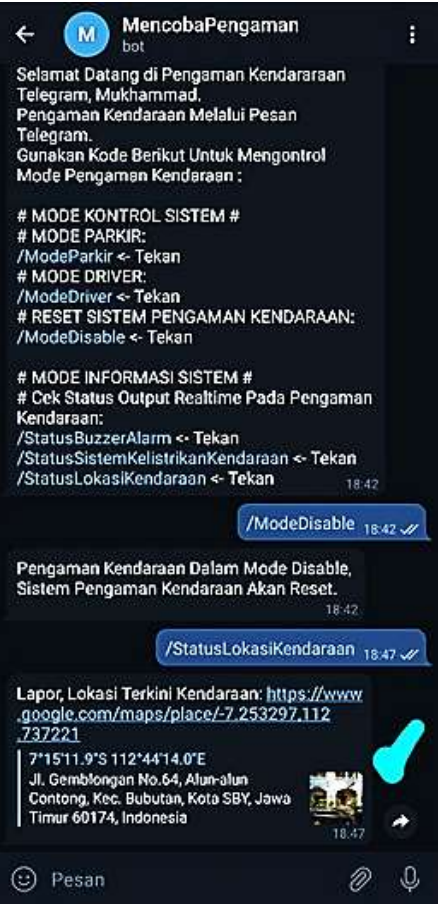

Gambar 24. Pesan /StatusLokasiKendaraan ke bot Telegram.

\section{PENUTUP}

\subsection{Kesimpulan}

Berdasarkan penelitian yang telah dilakukan maka didapat beberapa kesimpulan sebagai berikut:

1. Rancang bangun prototipe diawali dengan perancangan hardware sistem, setelah itu dilakukan perancangan software, membuat halaman monitoring thingspeak serta pembuatan program dan pengunggahan program pada software arduino ide.

2. Modul GPS Neo7MV2 berfungsi sebagai sensor penangkap sinyal GPS untuk melacak titik koordinat lokasi dan sensor getar SW420 berfungsi sebagai pendeteki getaran pada kendaraan ketika saat diposisikan parkir.

3. Saat diuji coba, tampilan display oled pada prototipe pengaman kendaraan berfungsi sebagai indikator display.

4. Cara menggetahui informasi sistem alarm kendaraan secara realtime dan mengontrol prototipe pengaman kendaraan dengan menggunakan pesan telegram yaitu dengan cara mengirimkan pesan mode informasi sistem atau mode kontrol sistem ke bot telegram yang telah dibuat.

5. Memantau lokasi kendaraan secara realtime dengan pesan telegram yang terintegrasi web server thingspeak yaitu dengan mengirimkan pesan /StatusLokasiKendaraan ke bot telegram. ini dilakukan untuk menggetahui status lokasi terkini kendaraaan dengan titik koordinat yang dikirim oleh bot telegram ke telegram pengguna.

6. Pengujian respon alat terhadap pesan telegram yang dikirimkan ke bot telegram dengan ratarata waktu respon balasan pesan yaitu 19.8 second. Pengujian lock sinyal GPS rata-rata waktu 266.67 second atau setara 44 menit 45 detik. Pengujian akurasi pembacaan data GPS rata-rata selisih jarak yaitu 19.99 meter. Pengujian sensor getar pada sistem, jika kondisi sensor mendeteksi getaran maka output sensor high sehingga buzzer aktif dan 
notifikasi pesan telegram masuk ke akun telegram pengguna.

\subsection{Saran}

Dalam penelitian ini adapun beberapa saran yang disampaikan guna untuk menyempurnakan sistem pengaman kendaran, antara lain:

1. Untuk pengembangan selanjutnya yaitu membuat tata letak sistem lebih minimalis sehingga box yang digunakan lebih minimalis dan tidak menggunakan banyak tempat.

2. Sebaiknya menggunakan mikrokontroler IOT (Internet of Things) yang lebih cepat koneksi serta respon terhadap pesan Telegram dan menambahkan modul kamera pemantau yang berfungsi sebagai sensor kamera untuk memotret pelaku apabila kendaraan sedang dicuri. Sehingga lebih mengenali pelaku tindak pencurian kendaraan.

3. Sebaiknya menggunakan modul GPS terbaru yang lebih cepat waktu lock sinyal dan dapat lock sinyal ketika kendaraan berada pada tempat tertutup (didalam gedung bertingkat, ruang bawah tanah, didalam rumah).

4. Membuat aplikasi pemantau live pergerakan koordinat GPS pengaman kendaraan dan monitoring sistem pengaman kendaraan.

\section{REFERENSI}

[1] D. Tantowi and Y. Kurnia, "Simulasi Sistem Keamanan Kendaraan Roda Dua Dengan Smartphone dan GPS Menggunakan Arduino," J. Algor, vol. 1, no. 2, pp. 9-15, 2020.

[2] M. A. Budiman, A. Z. Harefa, and D. V. Shaka, "Perancangan sistem pelacak gps dan pengendali kendaraan jarak jauh berbasis arduino," J. Tek. Informasi, pp. 9-15, 2020.

[3] E. D. Marindani, B. W. Sanjaya, and Gusmanto, "Rancang Bangun Sistem Peringatan Dini Dan Pelacakan Pada Kendaraan Sepeda Motor Dengan Menggunakan Mikrokontroler Arduino Nano," J. Elektro, vol. 2, no. 1, pp. 1-11, 2016.

[4] F. Baskoro and M. Thoriq, "Rancang Bangun Sistem Keamanan Kendaraan Bermotor Berbasis Internet of Thing Dengan Modul Nodemcu V3 Esp8266," J. Tek.
Elektro, vol. 09, no. 02, pp. 511-519, 2020.

[5] S. Rosidin, S. Alifah, and S. Mulyono, "Prototipe Sistem Monitoring Mobil Pembawa Makanan Berbasis Internet Of Thing ( IOT )", Diss. Teknol. Univ. Islam Sultan Agung Semarang, pp. 1-15, 2018.

[6] R. S. Abidin, D. Syauqy, and R. Maulana, "Pengembangan Sistem Tracking Lokasi Low Power Sleep Pada Wearable Device," J .Pengemb. Teknol. Inf. dan Ilmu Komput., vol. 2, no. 10, pp. 3569-3576, 2018.

[7] P. Sokibi, A. Widjaja, "Implementasi Perangkat IOT ( Internet Of Thing ) Sebagai Sistem Pemantau dan Pengendali Kendaraan", Budi Luhur Information Technology 15(1), pp. 1-8, 2018.

[8] J. C. Rusadi, Y. Huda, "Perancangan dan Pembuatan Sistem Keamanan Terintegrasi Pada Kendaraan Berbasis Mikrokontroler Atmega328," J. Voc. Tek. Elekronika dan Informatika, vol. 7, no. 1, 2019.

[9] S. D. Hariri, "Sistem Keamanan Kendaraan Dual GPS Tracker Yang Terintegrasi Dengan Mikrokontroler Arduino," 2018.

[10] I. P. (. P. D. F. Muhammad, "KEAMANAN NASIONAL," 10 Oktober 2014. [Online]. Available:

https://polmas.wordpress.com/2014/10/10/k eamanan-nasional/. [Accessed 1103 2021].

[11] A. Muhlisin, "SISTEM PENGAMAN KENDARAAN BERMOTOR DENGAN MENGGUNAKAN TELEPON SELULER BERBASIS MIKROKONTROLER AT89S51," 19 September 2012. [Online]. Available: https://eprints.uny.ac.id/5985/. [Accessed 11 Maret 2021].

[12] P. A. Rahma, "SISTEM PENGENDALIAN DAN MONITORING SUHU, KELEMBABAN TANAH DAN CAHAYA PADA MINIATUR SMART GREENHOUSE BERBASIS IOT," 07 Mei 2020. [Online]. Available: http://eprints.polsri.ac.id/8104/. [Accessed 12 Maret 2021].

[13] A. Saputri, "Pengertian, fungsi dan cara menggunakan bot telegram," 18 Mei 2019. [Online].

Available: https://www.bukugue.com/apa-itu-bottelegram/. [Accessed 12 Maret 2021]. 
Jurnal ELECTRON, Vol. 2, No.2, November 2021, Hal. 57-68

e-ISSN 2622-6588 / p-ISSN 2830-523X

DOI: 10.33019\electron.v2i2.1

[14] M. A. Amanaf, S. Anggraeni, and T. Syifa, "Rancang Bangun Sistem Monitoring Angkutan Umum Menggunakan Metode GPS Tracking Area Purwokerto," ELKHA J. Tek. Elektro Untan, vol. 11, no. 2, pp.128-135,2019, [Online]. Available: http://jurnal.untan.ac.id/index.php/Elkha/arti cle/download/33291/pdf.

[15] T. Handayani, "APLIKASI GLOBAL POSITIONING SYSTEM PADA ALAT BANTU TUNA NETRA," 18 Mei 2018. [Online]. Available: http://eprints.polsri.ac.id/4580/3/fileIII.pdf. [Accessed 13 Maret 2021].

[16] J. F. Saputra, M. Rosmiati, and M. I. Sari, "Pembangunan Prototype Sistem Monitoring Getaran Gempa Menggunakan Sensor Module SW-420," eProceedings Appl. Sci., vol. 4, no. 2442-5826, p. 2055, 2018, [Online].Available:

https://openlibrarypublications.telkomuniver sity.ac.id/index.php/appliedscience/article/vi ew/7170. 